\title{
PROFESINĖS LEKSIKOS VARIANTU KONKURENCIJA STUDENTŲ KALBOJE
}

\author{
Aušra Didjurgienė \\ Kauno kolegija \\ Giedrutė Grigonienė \\ Kauno kolegija, Lietuvos sveikatos mokslu universitetas
}

\begin{abstract}
Anotacija. Straipsnyje aptariamas profesinès leksikos variantiškumas studentu kalboje. Skirtinguose kalbininku darbuose variantiškumas traktuojamas ịvairiai, kartais variantiškumas lyginamas su konkurencija. Tai rodo, kad nerra visuotinai priimtinos ju sampratos. Straipsnyje analizuojami variantiškumo ir konkurencijos reiškiniai, apibrëžtas varianto ir konkurento santykis bei ju vartojimo tendencijos studentu profesineje kalboje.
\end{abstract}

Pagrindiniai žodžiai: profesinè leksika, variantiškumas, konkurencija.

\section{Ivadas}

Kaip kalbos reiškinys variantiškumas yra analizuojamas įvairiais aspektais, priklausomai nuo to, ką norima ištirti ir kokiu tikslu tai daroma (Čèsnienė, 2015: 163). Skirtingų tyrëjų darbuose variantiškumo, kaip ir konkurencijos, samprata labai ịvairuoja, kaskart vis iš naujo apibrèžiama ir aiškinama. Tai rodo variantiškumo problemos sudètingumą ir išsamesnių šios srities tyrimų trūkumą. Nepaisant sampratos įvairovès ar pozicijos, kurios laikantis variantiškumo (konkurencijos) reiškinys nuolat analizuojamas, visuotinai sutinkama, kad variantai kalbai yra būtini, o variantiškumą lemianti kalbos raiškos priemonių kaita yra kalbos raidos rezultatas. Vis dèlto dèl per didelio variantiškumo gali pasunkèti komunikacija ar net rastis nesusikalbejjimas.

Taigi šiame straipsnyje, remiantis empiriniu tyrimu, analizuojamas studentų profesinès leksikos variantų paplitimas vartosenoje bei variantų konkurencijos reiškiniai.

Tyrimo tikslas - išanalizuoti profesinès leksikos variantų konkurenciją studentų kalboje.

\section{Tyrimo uždaviniai:}

1. Apžvelgti mokslinèje literatūroje pateikiamas variantiškumo ir konkuren- 
cijos sampratas;

2. Aptarti profesinès kalbos leksemų variantus;

3. Nustatyti profesinès leksikos variantų vartosenos tendencijas studentų kalboje.

Tyrimo objektas - studentų profesinè kalba.

Tyrimo metodai:

1. Mokslinès literatūros analizè.

2. Studentų apklausa raštu.

3. Empirinio tyrimo rezultatų analizè, apibendrinimas, interpretavimas ir sisteminimas.

Straipsnị sudaro trys dalys. Pirmojoje dalyje apžvelgiama variantiškumo ir konkurencijos samprata, antrojoje aptariami galimi leksikos skolinių variantai, trečiojoje dalyje analizuojami empirinio tyrimo rezultatai.

\section{Variantiškumo ir konkurencijos samprata}

Skirtingų kalbininkų darbuose tiek konkurencijos, tiek variantiškumo sampratos aiškinamos nevienodai. Lietuvoje vienas pirmujų kalbos vienetų konkurencijos reiškinius aptare K. Župerka (1995:17), konkurentais ịvardydamas kalbos priemones, reiškiančias tą patị kalbinio bendravimo ketinimą, todèl galinčias viena kitą pakeisti, o būdingiausiais konkurentais laiko variantus, t. y. kalbos faktus, turinčius tą pačią reikšmę, sinonimus ir kt. Kiti mokslininkai konkurencijos reiškini apibrèžia šiek tiek kitaip. R. Vladarskienè (2003:63) konkurento sąvoką išplečia, konkurenciją aiškindama kaip santykị ,tarp kelių kalbos vienetų, turinčių tą pačią ar panašią reikšmę, iš kurių šnekos akto metu pasirenkamas vienas“, ji konkurentais vadina ,ir norminius kalbos variantus, ir svetimybes bei jų atitikmenis, ir terminu sinonimijos atvejus“. Vèliau konkurenciniais santykiais domèjosi ir daugiau tyrèjų: J. Girčienè (2005), L. Vaicekauskienè (2007), R. Miliūnaitė (2009), kurių darbuose daugiausia demesio skiriama naujųų svetimybių ir jų atitikmenų konkurencijai. Variantai taip pat suprantami nevienodai. Pavyzdžiui, K. Gaivenis, S. Keinys (1990: 225) variantą aiškina labai siaurai, teigdami, kad variantas - tai ,to paties kalbos vieneto skirtybe்“, paprastai jis turịs ,tą pačią funkciją ir skiriasi tik išraiška, dèl to tai yra skirtingos to paties atskiro kalbos vieneto realizacijos“. Tačiau yra ir platesnių varianto bei variantiškumo sampratos aiškinimų. Pasak R. Miliūnaitės (2009: 117), variantiškumas gali apimti ịvairius vartosenoje funkcionuojančius variantus, nepriklausomai nuo jų norminès vertès. Taigi, ị variantą ir variantiškumą, kaip ir i konkurencinius santykius, čia žvelgiama plačiai. Tokia nevienoda konkurencijos ir variantiškumo reiškinių samprata rodo, kad lietuvių kalbotyroje nèra nusistovèjusio ir visuotinai priimtino konkurento (konkurencijos) ir varianto (variantiškumo) apibrèžimo. Todèl tyrèjai jị apibrèžia taip, kaip tai daryti parankiausia atliekant konkretų tyrimą, vadinasi, priklauso nuo išsikelto tyrimo tikslo. Šiame straipsnyje laikomasi R. Miliūnaitès sampratos dẻl variantų ir konkurentų. 


\section{Leksikos skoliniai ir jų vertinimas}

Leksika - sparčiausiai kintantis kalbos sluoksnis. Skoliniai sudaro nevienalytị leksikos sluoksnį. Vieni jų vartojami visuotinai, nes lietuvių kalboje nèra jiems tinkamų atitikmenų, pvz.: arbata, muilas, popierius ir kt. Dar kiti skoliniai - svetimybès, hibridai, tarptautiniai žodžiai. „Svetimybès (barbarizmai) - tai žodžiai, neatitinkantys bendrinès lietuvių kalbos normų ir turintys lietuviškus atitikmenis“" (Kazlauskienè, 2011:58), pvz., štamas (= padermė), blisteris (= vaistų plokštelè), relaksas (= atsipalaidavimas) ir kt. Kita skolinių grupe - „hibridai - tai žodžiai, turintys iš kitų kalbų paskolintų darybos dėmenų (šaknị, priešdèlį, priesagą ar kamieną)..."(Leksika: skolinių vartojimas, 2013:6), pvz.: ekspresapklausa (= greitoji apklausa), autoịvykis (- eismo įvykis) ir kt. „Tarptautiniai žodžiai (internacionalizmai) yra tokie svetimžodžiai, kurie vartojami daugelyje pasaulio kalbų. Tarptautiniai žodžiai yra dvejopi: a) negalimi pakeisti savais, nes tie tarptautiniai žodžiai yra vieninteliai sąvokų pavadinimai..." (Kazlauskienė, 2011:58), pvz.: fakultetas, funkcija, rentgenas; b) galimi pakeisti savais, pvz.: pneumonija - plaučių uždegimas, simptomas - požymis, skeletas - griaučiai ir t. t.

Leksikos skoliniai vertinami vienu iš keturių galimų laipsnių. Pačiu griežčiausiu vertinimo laipsniu - neteiktina - ịvertinti žodžiai yra kalbos klaida, jie bendrinei kalbai neteiktini ir taisomi norminiu variantu, pvz.: tifas $n t k$. (= šiltinè), pilingas $n t k$. (= odos šveitimas). Kai kurie skoliniai, pavartojami tik tam tikroje srityje, tam tikro stiliaus tekstuose, vertinami kiek švelniau ir teikiami su nuoroda vengtina, pvz.: salvija svet. vngt. - bot. šalavijas, herpesas svet. vngt. - med. pūslelinè. Tarptautiniai žodžiai dažniausiai laikomi bendrinès kalbos normos variantais. Jie gali būti visiškai prilyginti saviesiems lietuviškiems atitikmenims, pvz.: implantas tarpt. | ìsodas, poligamija tarpt. | daugpatystè. Jei tarptautinis žodis turi tinkamą, tikslų prigijusį lietuvišką atitikmenị, tarptautinis žodis laikomas šalutiniu normos variantu, pirmenybė teikiama lietuviškam atitikmeniui, pvz.: skeletas tarpt. || anat. griaučiai, termoforas tarpt. || med. šildyklè.

Taigi dèl kai kurių leksemų, t. y. svetimybių ir neteiktinų hibridų vartojimo profesinejje kalboje gali rastis kalbos klaidų, todèl tikslinga stebėti šių leksemų paplitimą vartosenoje, kad būtų galima užkirsti kelią jų skverbimuisi ị kalbą.

\section{Empirinio tyrimo rezultatų analizė}

Studentams buvo pateiktas penkiasdešimties profesinès leksikos variantų poru sąrašas (1 lentelè), sudarytas pagal Leksikos skoliniu sąraša (2013), ir paprašyta kiekvienoje variantų poroje pažymėti respondentų vartosenai priimtiną variantą. Dvidešimt septynias variantų poras sudaro tarptautiniai žodžiai ir lietuviški jų atitikmenys (tarptautinis žodis vs. lietuviškas žodis), keturias variantų poras sudaro vengtini skoliniai ir lietuviški jų atitikmenys (vengtinas skolinys vs. lietuviškas žodis), devyniolika variantų porų sudarytos iš neteiktinų žodžių ir taisyklingų jų 
atitikmenų (neteiktinas skolinys vs. taisyklingas jo pakaitas). Apklausoje dalyvavo 200 biomedicinos mokslų studentų.

1 lentelè. Profesinès leksikos variantų poros

\begin{tabular}{|c|c|c|}
\hline 1 & abscesas & pūlinys \\
\hline 2 & absorbuoti & sugerti \\
\hline 3 & aromaterapija & kvapų terapija \\
\hline 4 & automasažas & savimasažas \\
\hline 5 & bandažas & vyturas \\
\hline 6 & bintas & tvarstis \\
\hline 7 & defektas & yda \\
\hline 8 & ekstraktas & ištrauka \\
\hline 9 & faktorius & veiksnys \\
\hline 10 & furunkulas & šunvotė \\
\hline 11 & genezè & kilmė \\
\hline 12 & implantas & įsodas \\
\hline 13 & incestas & kraujomaiša \\
\hline 14 & infekcija & užkratas \\
\hline 15 & invalidas & neigalusis \\
\hline 16 & ingredientas & sudedamoji dalis \\
\hline 17 & kariesas & èduonis \\
\hline 18 & karbunkulas & piktvote \\
\hline 19 & katarakta & lęšiuko drumstis \\
\hline 20 & manžetė & varžtis \\
\hline 21 & menstruacijos & mènesinès \\
\hline 22 & poligamija & daugpatystè \\
\hline 23 & sepsis & kraujo užkrètimas \\
\hline 24 & simptomas & požymis \\
\hline 25 & skeletas & griaučiai \\
\hline 26 & stresas & ittampa \\
\hline 27 & vakcina & skiepai \\
\hline 28 & ekstrinis & skubus \\
\hline 29 & herpesas & pūslelinè \\
\hline 30 & hospisas & slaugos ligoninè \\
\hline 31 & bicepsai & raumenys \\
\hline 32 & dedlainas & galutinis terminas \\
\hline 33 & glanda & tonzilè \\
\hline 34 & linzè & lęšis \\
\hline 35 & muskulatūra & raumenynas \\
\hline
\end{tabular}




\begin{tabular}{|l|c|c|}
\hline 36 & pampersas & sauskelnės \\
\hline 37 & pilingas & odos šveitimas \\
\hline 38 & presingas & spaudimas \\
\hline 39 & relaksas & atsipalaidavimas \\
\hline 40 & skryningas & medicininis patikrinimas \\
\hline 41 & šina & paderme் \\
\hline 42 & štamas & kaištis \\
\hline 43 & štiftas & kineziterapinis tvarstis \\
\hline 44 & teipas & šiltinè \\
\hline 45 & tifas & briliantinis žaliasis \\
\hline 46 & zelionka & vaistu plokštelè \\
\hline 47 & blisteris & premija \\
\hline 48 & bonusas & sultinys \\
\hline 49 & buljonas & lengvasis kultūrizmas \\
\hline 50 & fitnesas & \\
\hline
\end{tabular}

Išanalizavus tyrimo duomenis nustatyta, jog respondentai profesinėje kalboje vienodai dažnai vartoja tiek tarptautinius žodžius, tiek lietuviškus jų atitikmenis (52 proc. renkasi tarptautinį žodị, 48 proc. - lietuvišką jo atitikmenį). Kai kurie tarptautiniai žodžiai dideliu santykiu nukonkuruoja lietuviškus jų atitikmenis (1 pav.). Tyrimas parodè, jog studentai dažnai vartoja tokius tarptautinius žodžius kaip ingredientas ( 74 proc.), ekstraktas (68 proc.), bandažas (67 proc.), manžetė (65 proc.), skeletas (64 proc.), faktorius (57 proc.)

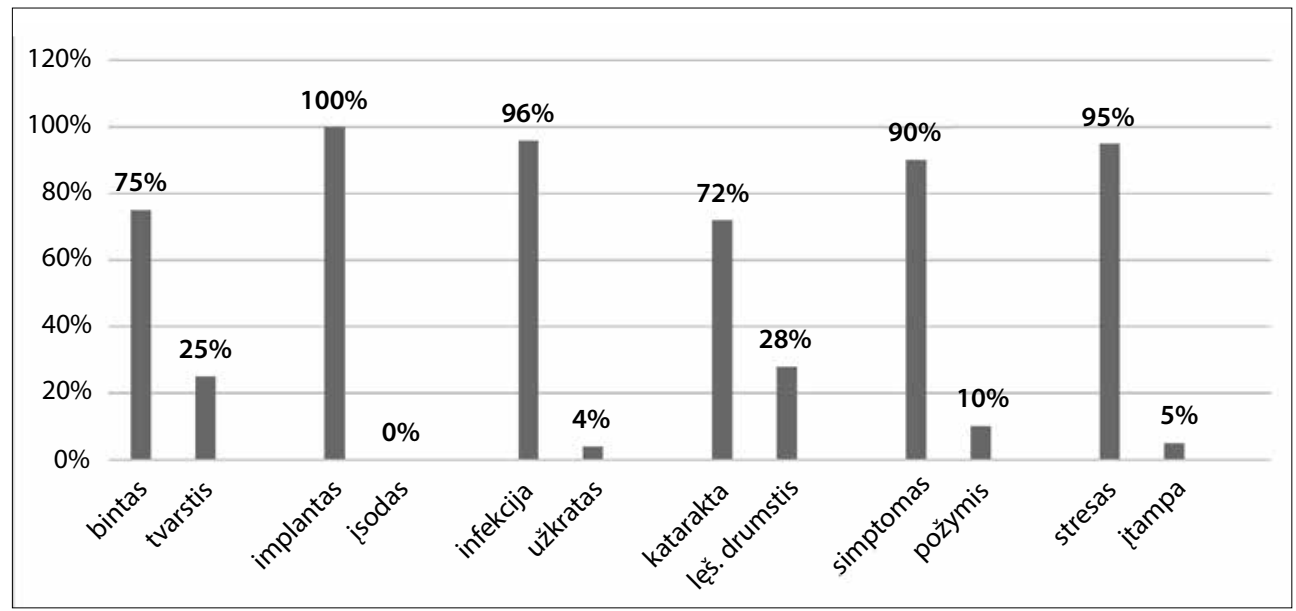

1 pav. Dažniausiai studentų vartojami tarptautiniai žodžiai 
Nors akademinė kalba pasižymi tarptautinių terminų gausa, tačiau kai kurie tarptautiniai žodžiai visiškai nepopuliarūs studentų profesinès kalbos vartosenoje (2 pav.).

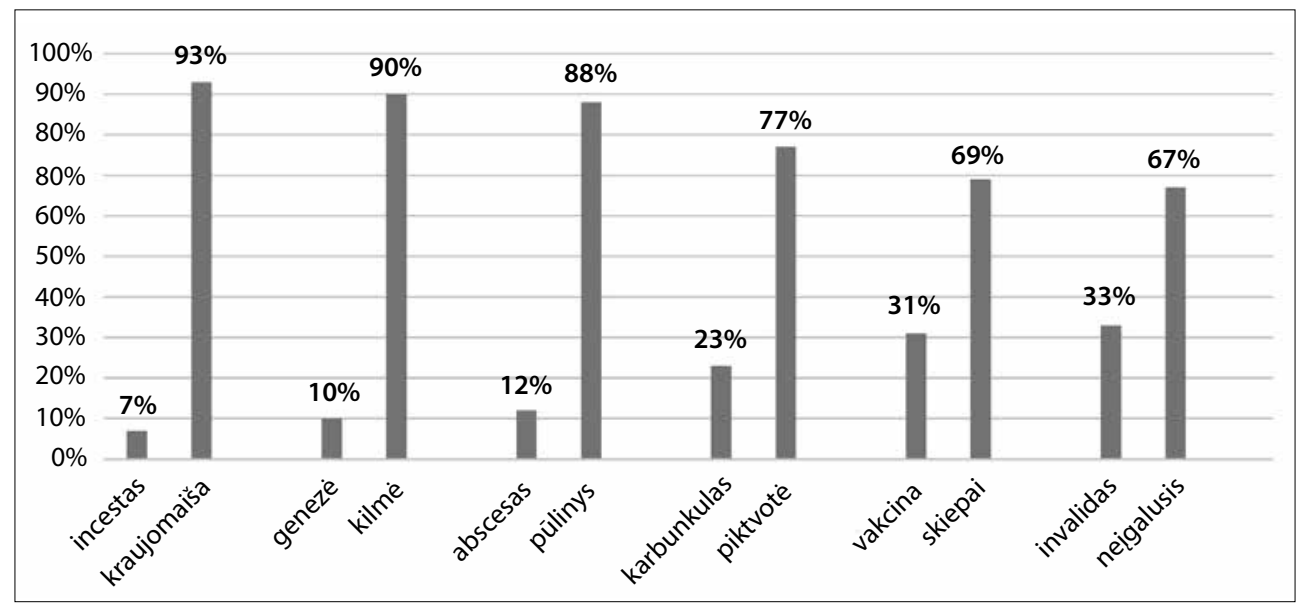

2 pav. Studentų profesinejje kalboje rečiausiai vartojami tarptautiniai žodžiai

Tyrimo duomenys parodè, jog dauguma apklausoje pateiktų vengtinų skolinių gana retai vartojami respondentų profesinèje kalboje (3 pav.). Džiugu, jog studentai teikia pirmenybę taisyklingiems lietuviškiems žodžiams.

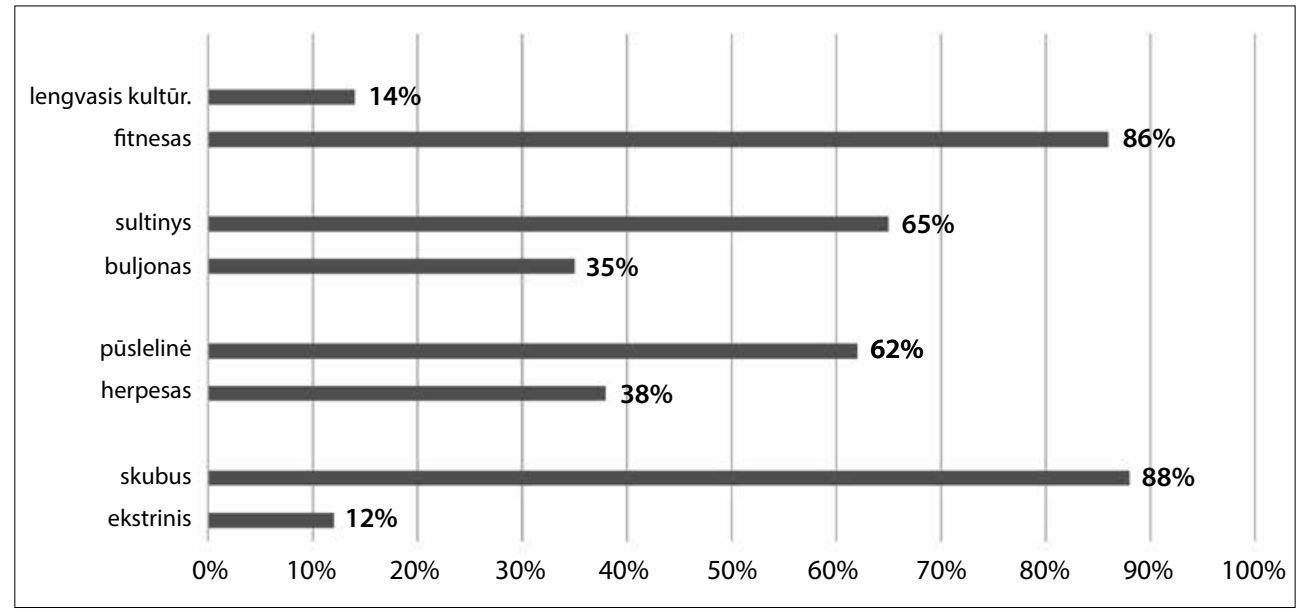

3 pav. Vengtinų skolinių ir lietuviškų jų atitikmenų konkurencija studentų kalboje

Analizuojant neteiktinų svetimybių konkurenciją su taisyklingais jų pakaitais studentu profesinëje kalboje, paaiškejjo, jog tik dvi svetimybès iš pateiktų anketoje respondentų profesinejje kalboje nukonkuruoja lietuviškus jų pakaitus (4 pav.). Labiausiai paplitusios svetimybès studentų kalboje - pampersai (58 proc.) ir zelionka 
(82 proc.). Tyrimo rezultatai parode, jog gana dažnai studentai vartoja tokias svetimybes kaip linze (28 proc.), teipas (28 proc.). Svetimybiu paplitimą profesinejje kalboje, tikètina, lemia privačioji vartosena. Tyrimo rezultatai leidžia manyti, jog studentai atpažista svetimybes, todèl jų profesiniame žodyne dominuoja taisyklingi žodžiai.

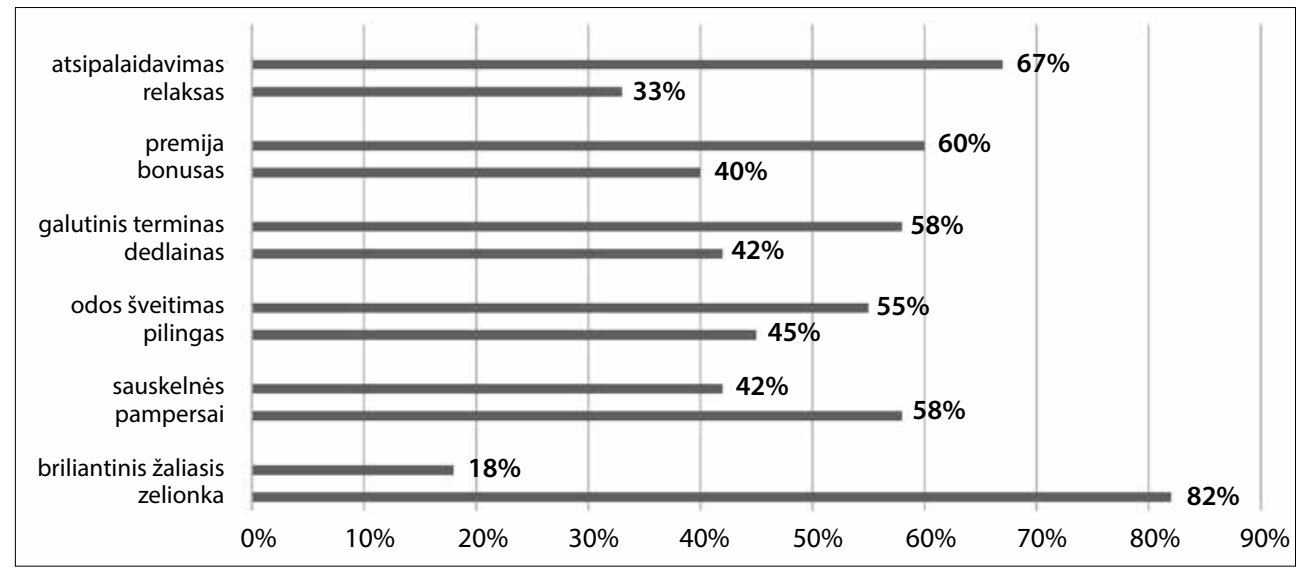

4 pav. Svetimybių vartosenos tendencijos studentų profesinèje kalboje

Tyrimo rezultatai parodè, kokių apklausos anketoje išvardytų svetimybių studentai beveik nevartoja (5 pav.).

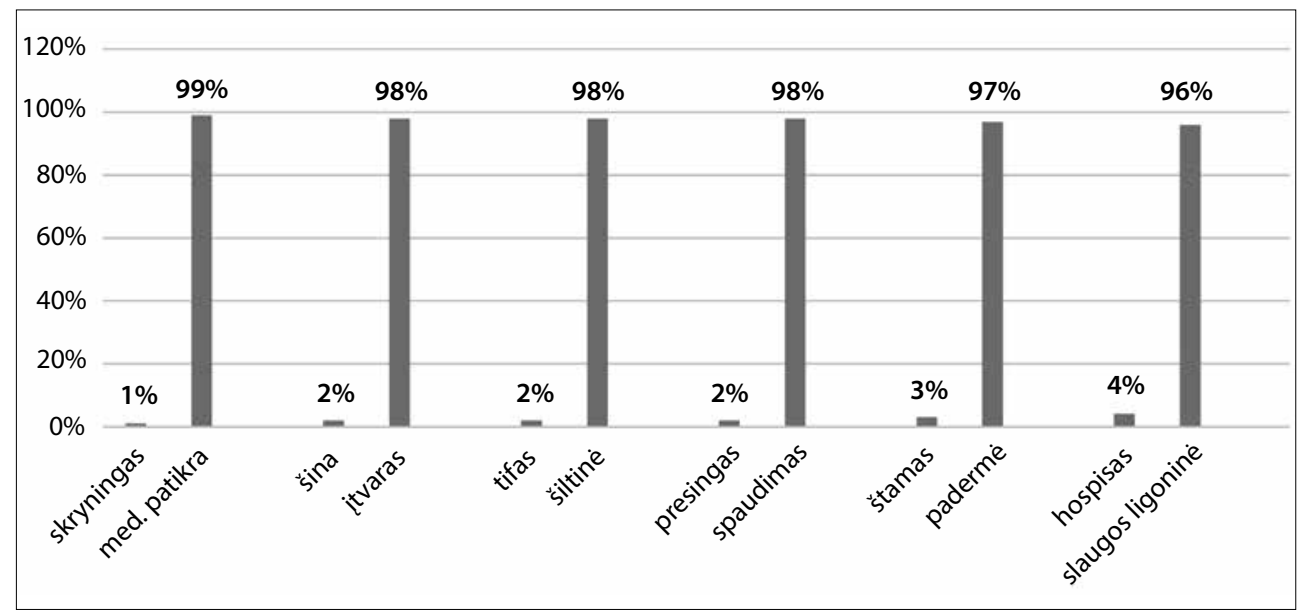

5 pav. Rečiausiai studentų vartojamos profesinès kalbos svetimybės 


\section{Išvados}

1. Mokslinèje literatūroje nèra nusistovèjusio, visuotinai priimto konkurento (konkurencijos) bei varianto (variantiškumo) apibrěžimo, tačiau pripažįstama, kad nors dèl per didelio variantiškumo gali pasunkèti konkurencija, variantai yra būtini, o variantiškumą lemianti kalbos raiškos priemonių kaita yra nulemta kalbos raidos proceso. Vieni kalbininkai konkurentais įvardina kalbos priemones, reiškiančias tą pati kalbinio bendravimo ketinimą, todèl galinčias viena kitą pakeisti (K. Župerka), kiti konkurentais vadina ir norminius kalbos variantus, ir svetimybes bei jų atitikmenis, ir terminu sinonimijos atvejus (R. Vladarskienè), treti variantais laiko tą pačią kalbos funkciją atliekančius, bet turinčius skirtingą išraišką kalbos vienetus (K. Gaivenis, S. Keinys). Straipsnyje profesinès leksikos variantų vartosenos tendencijos studentų kalboje analizuojamos remiantis platesne R. Miliūnaitės samprata, konkurentais laikančia bet kokius tą patị tikrovès objektą įvardijančius variantus, susijusius konkurenciniais varžymosi santykiais.

2. Profesinès kalbos leksemų variantų apžvalga leidžia konstatuoti, kad norint užkirsti kelią svetimybių ir neteiktinų hibridų skverbimuisi į kalbą, tikslinga stebèti jų paplitimą studentų profesinèje kalboje, vertinant skolinius vienu iš keturių galimų laipsnių: neteiktina, vengtina, bendrinès kalbos normos variantas, prilygintas saviesiems lietuviškiems atitikmenims, bei tarptautinis žodis, laikomas šalutiniu normos variantu, pirmenybė teikiama lietuviškam atitikmeniui.

3. Tyrimo duomenys leidžia teigti, kad opozicijoje tarptautinis žodis vs. lietuviškas žodis vartojami tiek tarptautiniai žodžiai (šiek tiek daugiau kaip pusè apklaustujų), tiek lietuviški jų atitikmenys (šiek tiek mažiau kaip pusė apklaustujų). Tarp dažniausiai lietuviškuosius atitikmenis nukonkuruojančių minètini ingredientas (renkasi trys ketvirtadaliai apklaustujų), ekstraktas, bandažas, manžetè, skeletas (renkasi apie du trečdalius apklaustujų), faktorius (renkasi daugiau kaip pusè apklaustujų). Visai nepopuliarūs ir šioje opozicijoje lietuviškiesiems žodžiams pralaimi tarptautiniai terminai incestas (7 proc.), geneze (10 proc.), abscesas (12 proc.), karbunkulas (23 proc.), vakcina (31 proc.), invalidas (33 proc.). Tyrimo duomenys parodè, kad opozicijoje vengtinas skolinys vs. lietuviškas žodis iš keturių pateiktų variantu porų tik vienas vengtinas skolinys fitnesas ryškiai nukonkuruoja lietuviškajji lengvaji kultūrizma. Analizuojant opoziciją neteiktinas skolinys vs. taisyklingas jo pakaitas pastebèta, kad iš 19 porų tik dvi svetimybès - pampersai ir zelionka gerokai nukonkuruoja lietuviškąsias sauskelnes ir briliantinị žaliajį. Galima pasidžiaugti, kad kiti neteiktini skoliniai arba gerokai pralaimi lietuviškiesiems variantams, arba apskritai beveik nevartojami studentų kalboje. 


\section{Literatūra}

1. Č̀snienè, Ž. (2015). Leksikos variantiškumas ir konkurencija Europos Sajungos dokumentų vertimuose. Prieiga internete: http://www.litlogos.eu/L86/Logos_86_161_171_Cesniene.pdf Šviesa.

2. Gaivenis, K., Keinys, S. (1990). Kalbotyros terminų žodynas. Kaunas:

3. Girčienè, J. (2005). Naujụjų skolinių atitikmenys: struktūra ir vartosena. Vilnius: Lietuvių kalbos institutas.

4. Kalbos patarimai 4. Leksika: skoliniu vartojimas (L 1). (2013). Sud. D. Mikulènienè ir A. Dvylyte. Vilnius: Mokslo ir enciklopedijų leidybos centras.

5. Kazlauskienè, A., Rimkute, E., Bielinskienè, A. (2011). Bendroji ir specialybès kalbos kultūra. Kaunas: VDU.

6. Miliūnaite, R. (2009). Dabartinès lietuvių kalbos vartosenos variantai. Vilnius: Lietuvių kalbos institutas.

7. Tarptautinių žodžių žodynas. (2013). Red. D. Svetikienė. Vilnius: Alma littera.

8. Vaicekauskienè, L. (2007). Naujieji lietuvių kalbos svetimžodžiai. Kalbos politika ir vartosena. Vilnius: Lietuvių kalbos institutas.

9. Vladarskienè, R. (2003). Sintaksinių struktūrų konkurencijos atvejai dokumentų kalboje. Lituanistica, 2 (54).

10. Župerka, K. (1995). Kalbos priemonių konkurencija kaip lietuvių kalbos stilistikos objektas. Šiauliai: Šiaulių universitetas. 


\title{
THE COMPETITION OF PROFESSIONAL LEXIS VARIANTS IN THE STUDENTS' LANGUAGE
}

\author{
Aušra Didjurgienè \\ Kaunas University of Applied Sciences \\ Giedrutė Grigonienė \\ Kaunas University of Applied Sciences \\ Lithuanian University of Health Sciences
}

The total stock of words in any language is called lexis. It is the fastest changing area of language alterations caused by the emergence of new things or phenomena in life. For naming them, words are borrowed or new ones are created. Loanwords, i.e. international or foreign words, often have Lithuanian equivalents or substitutes. It leads to several variants of the same lexeme, however, not all of them are appropriate for the use in general language, therefore, incorrect.

Language variability, i.e. the ability of a language to convey the same content through different means of expression, causes a long-standing interest for researchers. In contemporary linguistics, a considerable attention is paid to variability studies realizing that it is an inevitable consequence of language evolution, a regular expression of language changes. The variability in the Lithuanian linguistics is little investigated since practical issues of the standard language use are most often addressed. As a language phenomenon, variability is analyzed in various aspects depending on what is investigated and the purpose. In the works of different researchers, the concept of variability, as well as competition, varies widely and is always redefined and interpreted. It shows the complexity of variability and the lack of more detailed studies in this area. Regardless of the diversity of the concept or position according to which the phenomenon of variability (competition) is constantly analyzed, it is generally agreed that variants are necessary for a language, and the change of means of expression that determines variability is the result of the language development process. However, due to excessive variability, communication can be aggravated or even lead to miscommunication.

Professional lexis is also continuously renewing as new words are created, and new borrowings emerge. Thus, it is important to determine the use of patterns of vocabulary variants in the students' professional language in order to avoid inaccurate meanings of international and foreign words as well as unacceptable barbarisms and avoidable loanwords.

The aim of the research is to analyze the variability of professional lexis and the competition of variants in the students' language. 
The objectives of the research: literature;

1. To survey the concepts of variability and competition in scientific

2. To identify the competition of professional lexical variants in the students' language.

The object of the research is students' professional language.

The methods of the research:

1. The analysis of scientific literature;

2. Written survey of students.

The analysis of scientific literature revealed that variations in a language are necessary, and the change of the means of language expression determining variability is the result of language development. However, excessive variability can aggravate communication and cause mistakes in a language.

Based on the results of the empirical research, it can be stated that in the professional language students equally use international words and their equivalents in Lithuanian and Lithuanian language substitutes outrival avoidable loanwords and unacceptable barbarisms. 


\section{AUTORIAUS LYDRAŠTIS}

Autoriaus vardas, pavardė: Aušra Didjurgienè Mokslo laipsnis ir vardas: filologijos magistrè Darbo vieta ir pareigos: Kauno kolegija, lektorè Autoriaus mokslinių interesų sritis: specialybės kalbos didaktika Telefonas ir el. pašto adresas: +370 61096608 , ausra.didjurgiene@go.kauko.lt

Autoriaus vardas, pavardè: Giedrutė Grigonienè Mokslo laipsnis ir vardas: edukologijos ir filologijos magistre Darbo vieta ir pareigos: Kauno kolegija, lektorè Lietuvos sveikatos mokslų universitetas Autoriaus mokslinių interesų sritis: specialybės kalbos didaktika Telefonas ir el. pašto adresas: +370 67435 053, grig41@yahoo.com

\section{AUTHORS' COVER LETTER}

Author's name and surname: Aušra Didjurgienè Academic degree and name: Master of Philology Workplace and position: Lecturer, Kaunas University of Applied Sciences Author's research interests: didactics of professional language Telephone and e-mail address: +37061096 608; ausra.didjurgiene@go.kauko.lt

Author's name and surname: Giedrutė Grigonienè Academic degree and name: Master of Educology and Philology Workplace and position: Lecturer, Kaunas University of Applied Sciences; Lithuanian University of Health Sciences Author's research interests: didactics of professional language telephone and e-mail address: +370 67435 053; grig41@yahoo.com 